\title{
The Numerical Solution of the Aerodynamic Task Using by CFD Modelling
}

Josef Dobeš, Milada Kozubková

Department of Hydromechanics and hydraulic equipment, Technical University of Ostrava, 17. listopadu 15/2172 708 33 Ostrava, Czech Republic E-mail: josef.dobes@vsb.cz, milada.kozubkova@vsb.cz

The solution of the aerodynamic task is a very complex issue. An accurate description of the aerodynamic field is used for the specification and the solution of an aero-acoustic task. With the numerical modelling onset the possibilities of investigation of the flow around body are still expanding. The aim is to establish basic parameters by which the flow field around the body is described. This paper deals with the numerical modelling of the flow around a cylinder and a sphere and with the evaluation of the parameters (coefficients) for these bodies. The modelling is performed using the software tools Ansys Fluent and OpenFOAM. The basic setting of the numerical simulation is described and test of the calculation stability and mesh quality for a given task is done. The calculation setup is briefly shown for the computational tool OpenFOAM. At the same time, the experimental result is shown in this paper to verify the results of the numerical simulations. The experimental equipment $-\mathbf{a}$ wind tunnel is specified by its basic parameters and possibilities for the aerodynamic task measuring. Experimental data are obtained using by hot-wire anemometry - one-wire and two-wire probe.

Keywords: aerodynamic, numerical modeling, CFD code, simple body, hot-wire anemometer

\section{Acknowledgement}

This paper was funded by specific research on the Technical University of Ostrava named Zkoumáni dynamiky tekutinových systému, code SP2015/95.

\section{References}

[1] CONSTANTINESCU, G., SQUIRES, K. (2004). Numerical investigations of flow over a sphere in the subcritical and supercritical regimes. Physics of Fluids. vol. 16, issue 5, s. 1449-. DOI: 10.1063/1.1688325. Dostupné z: http://scitation.aip.org/content/aip/journal/pof2/16/5/10.1063/1.1688325

[2] HUCHO, W. (1998). Aerodynamics of road vehicles: from fluid mechanics to vehicle engineering. 4th ed. Warrendale: SAE International, c1998, xix, 918 s. ISBN 07-680-0029-7.

[3] ROSHKO, A. (1961). Experiments on the flow past a circular cylinder at very high Reynolds number. Journal of Fluid Mechanics. vol. 10, issue 03, s. 345-. DOI: 10.1017/S0022112061000950. Dostupné z: http://www.journals.cambridge.org/abstract_S0022112061000950

[4] SKOČILASOVÁ, B., SKOČILAS, J. (2013). Simulation of liquid flow in pipe. In: Manufacturing Technology, vol. 13, no. 4, p. 542-547, ISBN 1211-4162

[5] ANSYS FLUENT Theory Guide, Release 15.0. ANSYS, Inc., November 2013

[6] OpenFOAM The Open Source CFD Toolbox User Guide, Version 2.3.1. December 2014

[7] VERHOEVEN, O. (2011). Trailing Edge Noise Simulations using IDDES in OpenFOAM. Delft. Master of Science Thesis. Delft University of Technology, Aerospace Engineering. 